IZA DP No. 4656

Life-Cycle Patterns in Male/Female Differences in Job Search

Astrid Kunze

Kenneth R. Troske

December 2009 


\title{
Life-Cycle Patterns in Male/Female Differences in Job Search
}

\author{
Astrid Kunze \\ Norwegian School of Economics and Business Administration \\ and IZA \\ Kenneth R. Troske \\ University of Kentucky \\ and IZA
}

\section{Discussion Paper No. 4656 \\ December 2009}

\author{
IZA
}

P.O. Box 7240

53072 Bonn

Germany

Phone: +49-228-3894-0

Fax: +49-228-3894-180

E-mail: iza@iza.org

Any opinions expressed here are those of the author(s) and not those of IZA. Research published in this series may include views on policy, but the institute itself takes no institutional policy positions.

The Institute for the Study of Labor (IZA) in Bonn is a local and virtual international research center and a place of communication between science, politics and business. IZA is an independent nonprofit organization supported by Deutsche Post Foundation. The center is associated with the University of Bonn and offers a stimulating research environment through its international network, workshops and conferences, data service, project support, research visits and doctoral program. IZA engages in (i) original and internationally competitive research in all fields of labor economics, (ii) development of policy concepts, and (iii) dissemination of research results and concepts to the interested public.

IZA Discussion Papers often represent preliminary work and are circulated to encourage discussion. Citation of such a paper should account for its provisional character. A revised version may be available directly from the author. 
IZA Discussion Paper No. 4656

December 2009

\section{ABSTRACT}

\section{Life-Cycle Patterns in Male/Female Differences in Job Search ${ }^{*}$}

We investigate whether women search longer for a job than men and whether these differences change over the life cycle. Our empirical analysis exploits German register data on highly attached displaced workers. We apply duration models to analyze gender differences in job search taking into account observed and unobserved worker heterogeneity and censoring. Simple survival functions show that displaced women take longer to find a new job than comparable men. Disaggregation by age groups reveals that these differences are driven by differential behavior of prime age women. There is no significant difference in job search duration among the very young and older workers. These differential outcomes remain even after we control for differences in human capital, and when time dependence and unobserved heterogeneity are incorporated into the model.

JEL Classification: J31, J63, J64, J71

Keywords: gender differences, job search, displaced workers, wage differences, discrimination

Corresponding author:

Astrid Kunze

Norwegian School of Economics and Business Administration (NHH)

Helleveien 30

$\mathrm{N}-5045$ Bergen

Norway

Email: astrid.kunze@nhh.no

\footnotetext{
* The authors gratefully acknowledge the helpful comments we received in discussions with Maarten Lindeboom, Stefan Bender, Larry Kahn, Bruce Weinberg, Trond Olsen as well as in seminars at the Norwegian School of Economics and Business Administration, the University of Kentucky, University of Mannheim, ESEM in Barcelona, and the IAB in Nürnberg. We thank the IAB for granting us access to the data for this project. All remaining errors are our own responsibility.
} 


\section{Introduction}

One of the persistent questions in economics is whether the observed differences in wages between men and women reflect discrimination or unobserved differences in productivity or tastes. One possible difference between men and women that has received relatively little attention is differences in job search and job mobility. Previous work has found that mobility among young workers is an important source of wage growth (Topel and Ward, 1992; von Wachter and Bender, 2006); however, evidence for the U.S. and Germany suggests that young women change jobs less often than men and experience smaller gains in wages when they do switch jobs (Loprest, 1992; Fitzenberger and Kunze, 2005). Unfortunately, these finding are difficult to interpret because job movers are a select sample of workers, where the selection is often based on worker characteristics that are unobservable to the econometrician but are correlated with outcomes (Gibbons and Katz, 1991).

In this study we investigate gender differences in the duration of search and changes in wages after displacement, focusing on whether differences vary over the life cycle. In order to address some of the limitations of previous work, we exploit administrative panel data drawn from the German social security insurance program which consists of men and women with strong labor market attachments who were displaced from a job when their establishment closed. We follow displaced workers until they either obtain a new job or our data end. Our data cover the period from 1975 through 2001. Our assumption is that displacement is exogeneous to the worker so comparing the post-displacement search behavior of men and women will produce results that are less biased estimates of the differences in outcomes than comparing the behavior of all job movers. Our use of longitudinal administrative data ensures that we have an accurate measure of the length of displacement for all workers and 
our long panel minimizes the impact of censored spells. In addition, since we use administrative panel data where spell length is measured directly from the receipt of unemployment benefits we avoid some of the problems with previous studies that have relied on cross-sectional data (e.g. not knowing the length of time a worker searches, or having search length self-reported by the worker several periods after the time of displacement). Since our data contain a large sample of workers age 20-60, we are able examine how gender differences in search vary over the life cycle.

This study contributes new evidence on displaced workers in a European country to a literature that has been primarily shaped by studies on male displaced workers in the U.S. ${ }^{1}$ In addition, as far as we are aware, ours is the only study to examine the job search behavior of European women who have been displaced and to compare the behavior of men and women using European data. ${ }^{2}$ Finally, this study contributes to our understanding of the role that job mobility plays in producing the observed gender differences in labor market outcomes.

We apply duration models to analyze gender differences in job search taking into account observed and unobserved worker heterogeneity and censoring. One possibility we focus on is that male/female differences in search behavior vary over the life cycle because of women's role in child bearing and rearing. Since we do not have any information in our data on fertility and children, we use age to capture possible changes in the amount of women's nonmarket time devoted to children. We then test whether outcomes vary systematically over the life cycle in ways that are consistent with women's changing role in the household.

\footnotetext{
${ }^{1}$ See the articles in Kuhn (2002) for some exceptions to this statement.

${ }^{2}$ For a cross-gender comparison of the search behavior based on U.S. data see our companion paper Kunze and Troske (2009).
} 
Our empirical results show that women do experience longer spells of displacement and a larger drop in wages after displacement than men. However, when we examine these differences over the life cycle we find that the differences in job search are concentrated among workers age 24 to 35, which are prime child bearing and child rearing ages for women. Among younger and older workers we find that men and women exhibit similar lengths of displacement and similar changes in wages. While not conclusive, these results do suggest that differences in job search and mobility are related to fertility decision.

The remainder of the paper is as follows. In the next section we review the related work on displacement and job search. In Section III we describe our data and present some summary statistics. In Section IV we present our empirical results on displacement durations and in Section V on wages. In Section VI we discuss our results and present our conclusion.

\section{Previous Work Examining Male-Female Differences in Job Search}

The basic theoretical arguments that have been offered to explain why women search longer for a new job and why women receive lower wages operate through two main channels: differences in productivity and employer discrimination (e.g. Bowlus and Eckstein, 2002, Black, 1995). One shortcoming of these models is that they do not model differential outcomes as a function of worker demographics, such as age, that we find in our data.

To review the arguments we use as a framework the equilibrium search model by Bowlus and Eckstein $(2002)^{3}$, hereafter B\&E, where firms are searching over workers. In the B\&E model there are two types of workers, A and B, and two types of

\footnotetext{
${ }^{3}$ This model expands on the Black (1995) model, which focused on employment discrimination.
} 
firms, firms that receive some disutility from employing type B workers and firms that are indifferent between type A and B workers. We will focus on the situation where type A workers are men and type B workers are women. Employer discrimination in this model occurs when some fraction of employers experience a loss in utility from hiring women.

In B\&E it is assumed that all firms search less intensively for women if they are less productive, but prejudiced firms also search less intensively for women even if they are as productive as men. ${ }^{4}$ Call $\mathrm{P}_{\mathrm{i}}$ the productivity of type $\mathrm{i}$ workers ( $\mathrm{i}=\mathrm{A}$ or $\mathrm{B}$ ) and $\gamma_{d}$ the fraction of firms that receive disutility from hiring women. Consider the following two possible scenarios. First, suppose there exists only (unobserved) productivity differentials between the two groups of workers (and no discrimination) -that is $\mathrm{P}_{\mathrm{A}}>\mathrm{P}_{\mathrm{B}}, \gamma_{\mathrm{d}}=0$. Then all firms search less intensively for female workers because they are less productive. Second, suppose that workers are equally productive $\mathrm{P}_{A}=\mathrm{P}_{\mathrm{B}}$ but that there are some discriminatory firms in the market, i.e. $\gamma_{d}>$ 0. Then firms that experience a loss of utility when they hire women will search less intensively for women. ${ }^{5}$ In both of these cases the duration of unemployment will be higher for women. In addition, wages will be lower for women than men because, in the presence of some discriminatory firms, in equilibrium all firms can extract monopsony power and hence offer all women relatively lower wages.

Most previous empirical studies of displaced workers have focused on men or have pooled data for men and women. Simple comparisons of mean durations of displacement suggest that women take longer than men to find a new job after displacement (Podgursky and Swaim, 1987; Farber, 1997; Abbring et al., 2002; Kletzer and Fairlie, 2003; Hu and Taber, 2008). However, with the exception of Hu

\footnotetext{
${ }^{4}$ Search intensity is exogenous.

${ }^{5}$ If disutility firms would never hire female workers, then firms would be completely segregated.
} 
and Taber (2008), none of these studies has analyzed in detail the gender differences in displacement durations. ${ }^{6}$ An additional issue is that simple comparisons of mean duration among displaced workers can be misleading because durations are subject to censoring and are affected by worker heterogeneity.

The few studies that have examined gender differences in post-displacement wage outcomes have found mixed results. Early studies found that women experience larger wage losses after displacement (See Madden, 1987; Jacobson, et al. 1993, Crossley, et al., 1994) while later studies have found the opposite result (Kletzer and Fairlie, 2003). Further, there is no agreement on the mechanism that generates differential outcomes. ${ }^{7}$ No study that we are aware of investigates in any detail whether job search processes are different between men and women. ${ }^{8}$

Previous research on displacement that has compared data from North America with data from Europe has found striking cross-country differences. ${ }^{9}$ North American studies find that displaced workers tend to experience large and fairly persistent wage losses after displacement. In contrast, European studies find relatively small declines in wages and that workers transition relatively quickly to a new job. However, to the best of our knowledge, no study compares the experience of European men and women who have been displaced.

\footnotetext{
${ }^{6}$ Azmat, et al. (2006) have looked at cross-country variation in gender gap in unemployment rates. Their conclusion is that differential outcomes are mainly driveb by gender differences in human capital. Swaim and Podgursky (1994) have analyzed female labor supply employing a duration model.

${ }^{7}$ These conflicting results are somewhat puzzling because all of the studies use data for the US with exception of one study which is based on Canadian data.

${ }^{8}$ Crossley, et al. (1994) have suggested that gender differences in job search are important but have not empirically examined whether such difference exist.

${ }^{9}$ See the articles in Kuhn (2002).
} 


\section{The Data}

Our data on displaced workers come from the Institut fur Arbeitsmarkt und Berufsforschung Sample (IABS) data for the period 1975-2001. We focus on WestGermany. The IABS is a two percent random sample of workers drawn from the administrative data for the social security insurance program in Germany. The complete social security data are maintained by the German Federal Bureau of Labor and contain information for all workers who have at least one employment spell that is covered by the German social security system, which is approximately 80 percent of all workers in Germany in this period. Workers who are not included in these data are civil servants, self-employed workers and unpaid family workers. ${ }^{10}$ In order to maintain the representativeness of the IABS data, workers who retire and/or leave the labor market are replaced by workers who enter the labor market.

A major advantage of the administrative data is that the daily wage information reported in the data set is based on taxable income which makes this information highly reliable. While we do not have information on hours of work, and hence, hourly wages, we can distinguish part time workers (workers who work in a job less than 17.5 hours per week) from full time works. We will focus on workers who work at least 17.5 hours of work per week in their main job. Wage information in these data are top coded with the top code values changing over time. ${ }^{11}$ Finally, we drop all observations where a worker's wage is below the minimum social security level.

\footnotetext{
${ }^{10}$ For more details, see Bender et al. (1996), Bender, et al. (2000).

${ }^{11}$ Since less than 4 percent of men's wages and 2 percent of women's wages are top coded in our sample, this should not have any significant effect on our analysis. In order to test the sensitivity of our results to top coding we estimated both mean and median wage level and growth regressions and the two models produce similar estimates.
} 
The other major strength of these data is that they include very detailed employment history information. These data contain the exact date of any change in a worker's labor market status. This includes any switch between full and part-time work, any interruption in work, any movement to unemployment, and any change in employer. A worker is considered unemployed if he or she is in registered unemployment and is receiving unemployment insurance or unemployment assistance payments. Interruptions are reported by employers when the employer-employee relationship is on hold, but the contract is still valid. In this case no wage payments are made. Every other status results in a gap in the individual record.

Individual records in the IABS are organized in spells by calendar date. In addition to any change in labor market status, establishments have to report information about each employee by the first of January each year, so individual records contain at least one spell per year if they are employed in the year.

\section{A. Definition and identification of closing establishments and displaced workers}

We identify displaced workers in the IABS data through establishment closures. Every June, the unique identifier for the establishment where a worker is currently employed, along with data on the total number of employees in the establishment, is added to a worker's record. An establishment is considered closed when an identifier appears in one year, but does not appear in the subsequent year. All workers who are identified as having worked in an establishment in the year prior to the establishment disappearing from the data are considered displaced.

One problem with this method for identifying establishment closures is that it tends to overstate the number of closures (see Eliason and Storrie, 2006). This is because small establishments occasionally change identifiers when they change 
owners or for other unspecified reasons. To reduce these problems we focus on workers who work in establishments that have at least six workers in the last year they appear in the data. In addition, we exclude workers in the construction and retail sectors, since these sectors have a large amount of seasonal variation in the fraction of new and closing establishments. We also drop workers who switch jobs without experiencing a spell of unemployment.

To ensure that we focus on workers with strong labor market attachments, we only keep workers who have completed their education and who were displaced from a job where they worked at least 17.5 hours a week. ${ }^{12}$ We only keep workers who were between 20 and 60 years old at the time of displacement.

For each worker we keep up to four different displacement events. Around 20 (15) percent of male (female) workers in our sample were displaced more than once. In the following analyses we adjust all standard errors to reflect the fact that the same worker can appear multiple times in the data.

Our measure of the length of displacement is the duration of registered unemployment from the end of the displacement job until a worker finds a new job. We identify a worker's post-displacement job as the first job we see where the worker works more than 17.5 hours a week. Finally, we only keep workers for whom we have at least two years of data following the displacement event. Hence, in our data, 1999 is the last year a worker could be displaced.

We distinguish between three education groups: unskilled (10 or fewer years of compulsory schooling and less than 1.5 years of vocational training or college), skilled (10 years of schooling and an apprenticeship) and graduates (12 or 13 years of schooling and who have achieved a technical college degree or a university degree).

\footnotetext{
${ }^{12}$ Since for German men part-time work is of negligible importance this restriction primarily affects women.
} 
Graduates are underrepresented in our sample, primarily because the IABS does not contain civil servants and self-employed.

Actual experience is calculated for every individual throughout the period 1975-2001. Around 50 percent of workers have entered the labor market before 1975 and for those accumulated labor market experience in 1975 is adjusted by potential experience. We assume that graduates are not older than 23 in 1975, and everybody else is not older than 16 in $1975 .{ }^{13}$ Wages that are used are daily wages and are adjusted for inflation using the CPI index for West Germany. The base year is $1995{ }^{14}$

\section{B. The sample retained for analysis and summary statistics}

Our final sample of displaced workers from the IABS data contains 8820 displacement events; 5578 events for men and 3242 for women.

Table 1, Table 2, and Table 3 here

In Table 1 summary statistics for our sample of displaced workers are shown. Displaced workers are on average approximately 37 years old with displaced women being slightly younger than men. Once differences are adjusted for age men and women have similar weeks of experience. Recall we focus on workers who are working more than 17.5 hours a week when they are displaced, so we are selecting workers that are highly attached to the labor market. This could account for why men and women have similar levels of experience in these data. A large fraction of

\footnotetext{
${ }^{13}$ Potential experience is calculated as worker's age in the first spell observed, minus six minus years of education. We assume 9 years of schooling for the unskilled/low skilled workers, 11 years for skilled workers and 16 years for graduate workers.

${ }^{14}$ For a complete list of selection rules and their effect on the size of the sample see Appendix Table 1.
} 
workers in these data find a job after displacement. Around 69 percent of men and 63 per cent of women are observed in a post displacement job.

We observe differences in the level of education between men and women. Women are less educated than men in our sample with relatively more women classified as unskilled. Displaced workers are primarily skilled, which is not surprising since skilled workers are the largest group in the German labor market. Immediately prior to displacement, the unadjusted difference in daily wage between men and women working full-time is 34 percent.

Including censored spells we see that on average women's displacement duration is 42 weeks longer than men's. Comparing wages in the displacement and post-displacement jobs we see that men's wages fall by 7 percent while women's wages decline by 3 percent. ${ }^{15}$ While this fall in wages is significant, it is smaller than the decline found by previous studies conducted using U.S. data (see Jacobson et al., 1993). ${ }^{16}$ Women have on average six weeks longer tenure in the post-displacement job than men, which may indicate that women find better job matches. ${ }^{17}$ The data also capture typical differences between men and women in the probability of working full or part-time. Virtually all men work full- time, while 78 per cent of women do so before displacement. A substantial fraction of women changes to part-time work after displacement.

Table 2 shows the distribution of displacement events by age and sex. Note the relatively high share of young displaced workers in our sample and that the

\footnotetext{
${ }^{15}$ Conditional on re-employment in a full-time job women’s wages drop by 2.7 percentage points more than men's wages.

${ }^{16}$ We acknowledge that these results are not directly comparable since Jacobson, et al. (1993) estimate the wage loss after displacement by comparison of the actual wage to the expected wage. Expected wages are estimated from a control group (non-displaced workers).

${ }^{17}$ In the previous literature it has been shown that tenure is positively correlated with job match quality. Hence, better firm workers matches survive longer (Jovanovic, 1979).
} 
probability of displacement falls with age. Table 3 displays the length of displacement, in weeks, separately for men and women. Is is seen that women are less likely than men to find a job within 14 weeks of being displaced and more likely to wait over a year before finding a post-displacement job.

In order to describe male/female difference in durations of job search in more detail in Figure 1 we plot Kaplan-Meier survival functions for separately men and women. ${ }^{18}$ The survival function for women lies everywhere above the function for men. Hence, these unconditional estimates show that women tend to experience longer spells of displacement than men. ${ }^{19}$ Somewhat puzzling is the kink at around 52 weeks, which is more pronounced for women than for men. This means we find a jump in transitions out of unemployment into a new job for women after one year. ${ }^{20}$

Figure 1 here

To investigate how gender differences in search duration vary by age in Figures $2 \mathrm{a}$ and $2 \mathrm{~b}$ we plot survival functions by gender and for eight different age groups: 20 to 25,26 to 30,31 to 35,36 to 40,41 to 45,46 to 50,51 to 55 and 56 to 60. The figures demonstrate that the gender differences in the length of displacement are most pronounced among those workers under age 35 but tend to shrink among older workers. This is supported by statistical tests for the difference in the functions which show that the functions are significantly different among the younger workers,

\footnotetext{
${ }^{18}$ We only plot spells that are less than 300 weeks since there are very few spells lasting more than 300 weeks.

${ }^{19}$ The p-value of the rank test shows that the two functions are significantly different at standard levels of significance.

${ }^{20}$ Note that our measure of unemployment duration includes periods of receipt of unemployment insurance as well as unemployment assistance. Eligibility rules for the receipt as well as the duration of pay of unemployment insurance (Arbeitslosengeld) and unemployment assistance (Arbeitslosenhilfe) has been modified several times during our observation period. Changes are stated in the job employment act 1969 to 1997 and the social code (SGBIII) since 1997. To analyze how durations are affected by these changes goes beyond the scope of this paper. See e,g, Hunt (1995) for an analyses of changes on men's outcomes during the late 1980s and 1990s.
} 
but are not significantly different among the older workers. In addition, we see that the kink in the survival functions disappears for workers older than 45. Finally, looking at the functions for younger workers, we can see that much of the difference in search behavior is driven by the fact that men are more likely to find a job relatively quickly. After two years the probability of finding a job appears to be quite similar for men and women in the younger age categories.

Figure 2 here

\section{Analysis of the length of displacement}

To investigate how worker characteristics affect the length of displacement, and to test whether gender differences in job search durations are varying in age, we estimate a proportional hazard model. We specify the hazard rate as:

$$
\lambda_{u}\left(t \mid x, \beta_{u}\right)=\lambda_{0}(t) * \exp \left(x_{\text {pre }} \beta_{u}+\delta(\alpha) * \text { female }+\delta(\alpha)\right)
$$

where $\lambda_{\mathrm{u}}(\mathrm{t} \mid$.) is the transition rate from unemployment into employment at elapsed job search duration $t$ conditional on control variables, $x_{\text {pre }}$, measured in the last spell before displacement and an indiciator function in age that is interacted with a dummy variable for being female. The indicator function is defined as $\delta(\alpha)=\sum_{k} \delta_{k} I_{k}(\alpha)$ where the $\delta_{k}$ s are the key parameters and $I(\alpha)$ is a series of interval dummy variables with the intervals being: 20 to 25,26 to 30,31 to 35,36 to 40,41 to 45,46 to 50,51 to 55, and 56 to 60 years old. Alternatively, we estimate specifications using an indicator function with two year age brackets.

The vector of controls, $x_{\text {pre }}$ in the basic specification includes experience, experience squared, tenure, tenure squared, as well as dummy variables for education group (three groups), industry (fifteen groups), full time / part time, and calendar year. 
In extensions we include controls for occupation (eight groups). In the estimation all displacement events are pooled. Hence, we assume that these are random independent draws. We adjust standard errors to reflect the fact that a single individual can have multiple displacement events. In the tables we report estimates of the hazard ratios which shows the proportional change in the hazard when the variable is increased by one unit. A ratio of less than one indicates the hazard declines as the variable increases while a hazard ration of greater than one indicates a positive relationship between the hazard and the variable.

In Table 4 we report estimation results from the Cox proportional hazard model specified in equation (1). We see from the results in column 1 that the length of worker displacement rises fairly quickly with age. In addition, we see that more experienced workers tend to have shorter spells of displacement, workers who have longer tenure at the firm have longer spells of displacements, while more educated workers have shorter spells of displacement. All of these results are similar to results found by previous studies of displaced workers.

Table 4 here

Focusing on the coefficients on the interaction between the age categories and the female dummy variable we see that there is a distinct life-cycle pattern in the differences between men and women in the length of displacement. The coefficients on the female/age interactions show that the increased length of displacement among women occurs exclusively among women who are 35 years old or younger. For 
women 36-55 there is no significant difference in the length of displacement, and women 56-60 experience shorter lengths of displacement than men of similar age. ${ }^{21}$

In column 2 we present results from a model where we include a worker's occupation in the displacement job. Since there is some dispute regarding whether occupation controls should be included in analysis such as we are conducting, we decided to estimate models both excluding and including occupational controls. Comparing the results in columns 1 and 2 shows that including occupational controls has very little affect on the results. The only important differences are that, in column 2 it appears that women age 51-55 experience significantly longer spells of displacement than similarly aged men, while the coefficient on the female age 56-60 interaction becomes insignificant.

To examine how sensitive our results are to spells from people who are displaced more than once, column 3 presents results from the model estimated on a sample that only includes a person's first displacement spell. Comparing the results in column 3 with those in column 1 shows that the results from the two samples are quite similar.

One possibility is that the observed pattern is being produced by the use of five year age categories. To examine this possibility, in Table 5 we present results from a duration model that is identical to the model used in Table 4, except now we use two-year age categories. Using these smaller age categories shows the same lifecycle patterns seen in Table 4. It continues to be the case that longer spells of displacement for women are concentrated exclusively among women between the ages of 25 and 34. For all other ages we find no statistical differences between men and women in the length of displacement.

\footnotetext{
${ }^{21}$ This could reflect positive selection into work. Those with potentially long spells transition into early retirement.
} 
Table 5 here

Another possibility is that cohort effects may be producing the observed pattern. That is, it may be that there are smaller differences in the length of displacement among the older cohort of workers who will tend to dominate the older age categories. To examine this possibility in Table 6 we present the results from our basic model estimated separately on four different cohorts of workers: workers born between 1951 and 1955, workers born between 1956 and 1960, workers born between 1961 and 1965 and workers born between 1966 and 1970. We focus on these cohorts because other cohorts have too few observations. While less precisely estimated than our estimates based on the full sample, the coefficients on the age-female interactions show that same basic pattern as before. The difference in length of displacement primarily occurs among the younger workers with prime age men and women experiencing similar lengths of displacement. ${ }^{22}$

Table 6 here

All of our estimates so far have assumed that the baseline hazard is proportional across the groups and remains constant regardless of the length of the spell. This assumption may be too restrictive. One possibility is that the baseline hazard, $\lambda_{0}$,varies with the spell length. If this is the case, and we impose a constant baseline hazard over time, then we will have a mis-specified model and our coefficients could be biased. In order to examine this possibility we estimate a

\footnotetext{
${ }^{22}$ Note that effects for the age groups older than 51 years cannot be estimated since our panel data end in 2001 .
} 
proportional hazard model where we allow the baseline hazard to vary by the length of the spell. To do so we split the spell durations into 26 week segments up to 260 weeks. For spells longer than 260 weeks, we again impose the assumption that the baseline hazard remains constant.

Table 7 here

The results from this alternative specification are presented in Table 7, column $1 .^{23}$ Column (1) shows that there is strong evidence of time dependence-individuals who have been out of work relatively longer have a significantly lower probability of returning to work than individuals who have lost their job more recently. At the same time, the hazard ratios on the age-female interaction variables are almost identical to our previous results (table 4, column 1).

Another concern is that time dependence in these estimates actually picks up the change in the composition of high and low ability individuals. The high ability individuals leave first and therefore those remaining become more and more negatively selected which then explains the relatively low exit rate from unemployment. To incorporate unobserved heterogeneity of this form we extend our model in equation (1) as follows:

$$
\lambda_{u}\left(t \mid x, \beta_{u}, v\right)=\lambda_{0}(t) * \exp \left\{x_{p r e} \beta_{u}+\delta(\alpha) * \text { female }+\delta(\alpha)\right\} * v
$$

Where $v$ is an individual specific unobserved heterogeneity component. We assume that $v$ is orthogonal to the x's and that is has the inverse gamma distribution. In column (2) results are presented from the proportional hazard model with time

\footnotetext{
${ }^{23}$ We experimented with shorter periods and got similar estimates.
} 
dependence and with unobserved heterogeneity. ${ }^{24}$ The general findings on time dependence and control variables are virtually unaffected and hence unobserved heterogeneity does not not explain our previous findings. The hazard ratios for the variables on age interacted with female decrease somewhat but there is no change in significance.

As a final robustness test we estimate a mixed proportional hazard model using the exponential distribution for the hazard, and assuming the inverse Gaussian distribution for the unobserved heterogeneity component. This model relies more on distributional assumptions and is therefore more parametric. In this model the hazard rate after integrating out the unobservable individual fixed components is not proportional. The results from this model are shown in column 3 and the main results are unchanged. While we prefer estimates from the less parametric Cox proportional hazard model (table 4, column 1) we view these results as evidence of the robustness of our main findings.

\section{Wages After Displacement}

Equilibrium search models with discrimination (e.g. Bolwus and Eckstein, 2002) can generate the outcome that on average women search longer for a new job and have lower wages than men. In this section we examine the gender wage gap in postdisplacement wages and whether the differences in search behavior affect the male/female wage gap. We follow the same strategy that we followed in the previous section, by examining how wage levels and wage changes differ between men and women over the life-cycle. Note that we condition on re-employment which may introduce selection bias since workers who become re-employed may not be a random

\footnotetext{
${ }^{24}$ Since we observe too few individuals with multiple displacement spells we cannot exploit those to estimate the distribution of unobserved heterogeneity. Instead we rely on distributional assumptions.
} 
sample of all workers who lose their job. We will discuss implications of this possible nonrandom selection at the end of the section. Note that all regressions include dummy variables for year which capture aggregate time varying shocks.

Table 8 here

Table 8 shows the results from a regression where the log of daily wages in the post-displacement job is the dependent variable. Because we only have data on daily wages, and do not have detailed information on hours worked, we only include workers with full-time jobs in our analysis. All of our control variables are measured at the last spell before displacement. We include the same set of controls that we did in our hazard models, with the exceptions that we have dropped potentially endogenous variables, such as the tenure variables and the controls for industry.

The results in column 1 show that, when we include our basic set of controls, women's wages are approximately 27 percent less than men's wages. The results in column 2 show that including controls for age do not affect the estimated male/female wage gap. The results in column 3, where we have included an interaction between the female dummy and the age variables, show no distinct age pattern in the male/female wage gap. Finally, in column 4 we include controls for the length of displacement in months. Here we see that workers that are displaced for longer have lower wages.

Table 9 here 
Of course, showing that women earn lower wages than men in their postdisplacement job does not tell us much about the impact of search on wages, since women likely earned less than men in their pre-displacement job. In order to examine the differential impact of displacement and search on wages, in Table 9 we present regressions where the dependent variable is the change in log wages between the preand post-displacement job. ${ }^{25}$ In column 1 we see that, conditional on education and experience, women experience approximately a 3 percent larger drop in wages after displacement than men. In column 2 we see that controlling for age has very little effect on this mean gender difference-wages significantly increase with age (conditional on the fixed effects) among displaced workers.

While the results in column 3 show that women age 20 to 25 and 46 to 50 do seem to experience larger wage losses after displacement than men, for the rest of the age groups there is no significant gender difference. While it seems that the youngest women in our sample fall slightly behind comparable men in terms of wages, there is no significant difference between the age groups.

This suggests that the life-cycle pattern in job displacement durations is not related to wages or wage changes. To examine this possibility further, in column 4 we include the length of displacement in the regression. Here we can see that while the coefficient on the months of displacement variable is significant, it has very little impact on the female-age interaction coefficients. Apparently the fact that young women tend to experience longer spells of displacement does not entirely account for their greater wage loss. One should keep in mind that these wage regressions are for full-time workers and are conditional on re-employment and do not account for the possible non-random selection into re-employment. Assuming that workers who were

\footnotetext{
${ }^{25}$ Again we focus on full-time workers and those re-employed.
} 
employed before displacement are tightly attached to the labor market, that displacement is exogeneous and that displacement does not have a differential impact on men and women these estimates would be consistent estimates of the effect of displacement on the gender wage gap. However, if after displacement only the most able women search for a new job while a random sample of men search then these estimates would understate the effect of displacement on the gender wage gap. Conversely, if the opposite is true-only the most able men search for a new job after displacement while a random sample of women search-then these estimates overstate the impact of displacement on the gender wage gap.

\section{Discussion of the results and concluding remarks}

Our empirical analysis shows that at the mean women experience both longer spells of unemployment and a larger decline in wages than men after being displaced. Both of these findings are consistent with equilibrium search models such as Bowlus and Eckstein (2002) and Black (1995) if women are either less productive or experience labor market discrimination. However, a more detailed look at displacement durations shows that the differences vary across the life cycle and are concentrated among workers age 20-35. This observed life-cycle pattern is quite similar to the pattern we find when we conducted an analysis using data on displaced workers in the U.S. (Kunze and Troske, 2009). Overall the distinct life-cycle pattern seems inconsistent with either the B\&E or Black models. With one or two exceptions, there are no significant differences in the wage change among younger or older workers. $^{26}$

\footnotetext{
${ }^{26}$ Kunze and Troske (2009) found no significant gender differences in conditional post-displacement wage levels including controls for fertility.
} 
The obvious question is then, what economic mechanism could generate the observed life-cycle pattern in job search durations? One possibility is that women's opportunity cost of working varies over the life-cycle. In particular, women who are displaced when they are in prime child bearing years choose to remain out of the labor market for a longer period than men in order to have and then raise children. We present some direct evidence supporting this hypothesis in our companion paper based on U.S. data (Kunze and Troske, 2009). In this companion paper we show that, once we focus on women who do not have a child after being displaced, men and women have similar lengths of displacement across all age groups. Unfortunately, we cannot perform a similar analysis using the German data. However, the results in both papers suggest that the fertility decisions of women have a significant impact on women’s labor market mobility. 


\section{References}

Abbring, Jaap, Gerard J. van den Berg, Pieter A. Gautier, A. Gijsbert C. van Lomwel, Jan C. van Ours, and Christopher J. Ruhm, 2002. "Displaced Workers in the United States and the Netherlands.” In Peter J. Kuhn (ed.), Losing work, moving on : Worker Displacement in International Perspectives, (ed.) , W.E. Upjohn Institute for Employment Research, Kalamazoo, Michigan.,pp. 105194.

Azmat, Ghazala, Maia Güell and Alan Manning, 2006. "Gender Gaps in Unemployment Rates in OECD countries." Journal of Labor Economics, 24(1), 1-37.

Bender, Stefan, Jürgen Hilzendegen, Gőtz Rohwer and Helmut Rudolph, 1996. "Die IAB-Beschäftigtenstichprobe 1975-1990 - The IAB employment sample 1975-1990.” BeitrAB 197, Institut für Arbeitsmarkt- und Berufsforschung, Nürnberg.

Bender, S, A. Haas and C. Klose, 2000. "The IAB Employment Subsample 19751995.” Schmollers Jahrbuch Zeitschrift für Wirtschafts- und Sozialwissenschaften/Journal of Applied Social Science Studies, 120(4): 64962.

Black, Dan A., 1995. "Discrimination in an Equilibrium Search Model.” Journal of Labor Economics, Vol. 13, (April): 309-334.

Bowlus, Audra J. and Zvi Eckstein, 2002. "Discrimination and skill differences in an equilibrium search model.” International Economic Review, 43(4), 1309-1345.

Crossley, Thomas F., Stephen R.G. Jones and Peter Kuhn, 1994. "Gender Differences in Displacement Cost: Evidence and Implications." Journal of Human Resources, 29(2): 461-480.

Eliason, Marcus and Donald Storrie, 2006. "Lasting or Latent Scars? Swedish Evidence on the Long-Term Effects of Job Displacement." Journal of Labor Economics, 24(4), 831-856.

Farber, Henry S., 1997. "The Changing Face of Job Loss in the United States, 19811995.” Brookings Papers on Economic Activity: Microeconomics, 55-142.

Fitzenberger, Bernd and Astrid Kunze, 2005. "Vocational Training and Gender: Wages and Occupational Mobility among Young Workers.”, Oxford Review of Economic Policy, 21(3), pp.392-415.

Gibbons, Robert and Lawrence Katz, 1991. “Layoffs and Lemons.” Journal of Labor Economics, 9, 351-380. 
Hu, Luojia and Christopher Taber, 2008. "Displacement, Asymmetric Information and Heterogeneous Human Capital”, Federal Reserve bank of Chicago, WP 2008-2.

Hunt, Jennifer, 1995. "The Effect of Unemployment Compensation on Unemployment Duration in Germany.” Journal of Labor Economics, 13(1), 88-120.

Jacobson, Louis., Robert LaLonde and Daniel G. Sullivan, 1993. "Earnings Losses of Displaced Workers.” American Economics Review, 83(4), 685-709.

Jovanovic, Boyan, 1979. "Job Matching and the Theory of Turnover.” Journal of Political Economy Vol. 87 (Oct.): 972-990.

Kletzer, Lori and Robert W. Fairlie, 2003. The Long-Term Costs of Job Displacement for Young Adult Workers. Industrial and Labor Relations Review Vol. 56 (July): 682-698.

Kuhn, Peter J., 2002. Losing work, moving on: Worker Displacement in International Perspectives, (ed.) , W.E. Upjohn Institute for Employment Research, Kalamazoo, Michigan.

Kunze, Astrid and Kenneth R. Troske, 2009. "Comparative Advantage or Discrimination? Studying Differences in Male-Female Labor Market Dynamics using Displaced Workers”, mimeo.

Loprest, Pamela J., 1992. Gender Differences in Wage Growth and Job Mobility, American Economic Review, 82(2), 526-532.

Madden, J., 1987 "Gender differences in the cost of displacement: An empirical test of discrimination in the labor market," American Economic Review, 77(2): 246-51.

Podgursky, M. and Paul Swaim, 1987. "Job displacement and Earnings Loss: Evidence from the Displaced Worker Survey,” Industrial and Labor Relations Review, 41(1): 17-29.

Swaim, Paul and Michael Podgursky, 1994. Female Labor Supply following Displacement: A Split-Population Model of Labor Force Participation and Job Search, Journal of Labor Economics, 12(4), 640-656.

Topel, Robert H. and Michael P. Ward, 1992. "Job Mobility and Job Careers of Young Men”, The Quarterly Journal of Economics, 107(2), pp.439-479.

Von Wachter, Till and Stefan Bender, 2006. "In the Right Place at the Wrong Time: The Role of Firms and Luck in Young Workers' Careers.” American Economic Review, 96(5), pp. 1679-1705. 
Table 1: Summary statistics - sample of displaced workers age 20-60 from IABS 1975-2001

\begin{tabular}{lcccccc}
\hline \hline & \multicolumn{2}{c}{ All } & \multicolumn{2}{c}{ Men } & \multicolumn{2}{c}{ Women } \\
& Mean & $\begin{array}{c}\text { Standard } \\
\text { Deviation }\end{array}$ & Mean & $\begin{array}{c}\text { Standard } \\
\text { Deviation }\end{array}$ & $\begin{array}{c}\text { Mean } \\
\text { Deviation }\end{array}$ \\
\hline Proportion Female (\%) & 37 & & 0 & --- & 100 & -- \\
Age prior to displacement & 37.26 & 11.30 & 37.45 & 11.06 & 36.95 & 11.69 \\
Weeks of experience prior to displacement & 900.79 & 663.70 & 926.64 & 665.00 & 856.32 & 659.17 \\
Weeks of tenure in displacement job & 109.70 & 150.43 & 103.10 & 147.86 & 121.05 & 154.10 \\
Proportion unskilled & 0.37 & 0.48 & 0.34 & 0.47 & 0.42 & 0.49 \\
Proportion skilled (vocational training) & 0.61 & 0.49 & 0.63 & 0.48 & 0.56 & 0.50 \\
Proportion graduate & 0.02 & 0.15 & 0.03 & 0.16 & 0.01 & 0.12 \\
Proportion post displacement job observed & 0.66 & 0.47 & 0.69 & 0.46 & 0.63 & 0.48 \\
Length of displacement/unemployment (in weeks) & 230.93 & 342.68 & 215.26 & 332.44 & 257.88 & 358.08 \\
Proportion full time in displacement job & 0.91 & 0.28 & 0.99 & 0.08 & 0.78 & 0.42 \\
Proportion full time job in first post displacement job* & 0.86 & 0.34 & 0.97 & 0.16 & 0.66 & 0.47 \\
Tenure in post displacement job in weeks* & 89.55 & 112.54 & 87.27 & 113.03 & 93.83 & 111.52 \\
Log real daily wage displacement job (only full-time workers) & 4.73 & 0.46 & 4.83 & 0.41 & 4.49 & 0.47 \\
Log real daily wage post displacement job (only full-time worker & 4.68 & 0.40 & 4.76 & 0.35 & 4.46 & 0.42 \\
Number of individuals & 7212 & & 4437 & & 2775 & 3242 \\
Number of displacement observations & 8820 & & 5578 & & \\
\hline \hline
\end{tabular}

Note: *These means only include non-censored observations. 
Table 2: Distribution of age (percent)

\begin{tabular}{cccc}
\hline \hline Age & All & Men & Women \\
\hline $20-25$ & 18.28 & 16.37 & 21.56 \\
$26-30$ & 16.89 & 17.00 & 16.72 \\
$31-35$ & 14.57 & 15.72 & 12.58 \\
$36-40$ & 12.09 & 13.28 & 10.02 \\
$41-45$ & 10.91 & 10.94 & 10.86 \\
$46-50$ & 9.91 & 9.65 & 10.36 \\
$51-55$ & 9.74 & 9.27 & 10.55 \\
$56-60$ & 7.62 & 7.78 & 7.34 \\
\hline \hline
\end{tabular}

Note: Sample of displaced workers age 20-60 from IABS 1975-2001.

$\mathrm{N}=5578$ for men and $\mathrm{N}=3242$ for women.

Table 3: Distribution of Individual Durations of Displacement Events (percent)

\begin{tabular}{lccc}
\multicolumn{1}{c}{ Weeks } & All & Men & Women \\
\hline Less than 14 weeks & 31.0 & 34.0 & 25.6 \\
15 to 20 & 7.0 & 7.3 & 6.3 \\
21 to 32 & 8.4 & 8.6 & 7.8 \\
33 to 52 & 8.7 & 7.6 & 10.6 \\
53 and more & 44.8 & 42.0 & 49.4 \\
\hline \hline
\end{tabular}

Note: Sample of displaced workers age 20-60 from IABS 1975-2001. 
Table 4: Proportional Hazard Estimation of the Length of Displacement

\begin{tabular}{|c|c|c|c|}
\hline & $\begin{array}{l}\text { Entire Sample } \\
\text { (1) }\end{array}$ & $\begin{array}{l}\text { Entire Sample } \\
\text { (2) }\end{array}$ & $\begin{array}{l}\text { Sample } \\
\text { (3) }\end{array}$ \\
\hline Age 26-30 & $.789(.046)^{* * *}$ & $.788(.046)^{* * *}$ & $.765(.048)^{* * *}$ \\
\hline Age 31-35 & $.673(.047)^{* * *}$ & $.674(.047)^{* * *}$ & $.667(.050)^{* * *}$ \\
\hline Age $36-40$ & $.632(.055)^{* * *}$ & $.632(.055)^{* * *}$ & $.612(.058)^{* * *}$ \\
\hline Age 41-45 & $.559(.057)^{* * *}$ & $.553(.057)^{* * *}$ & $.562(.065)^{* * *}$ \\
\hline Age 46-50 & $.504(.059)^{* * *}$ & $.502(.059)^{* * *}$ & $.512(.069)^{* * *}$ \\
\hline Age 51-55 & $.354(.050)^{* * *}$ & $.350(.049)^{* * *}$ & $.382(.063)^{* * *}$ \\
\hline Age $56-60$ & $.093(.019)^{* * *}$ & $.092(.019)^{* * *}$ & $.093(.022)^{* * *}$ \\
\hline Female*Age20-25 & $.887(.051)^{* *}$ & $.902(.053)^{* *}$ & $.922(.057)$ \\
\hline Female *Age 26-30 & $.705(.047)^{* * *}$ & $.720(.049)^{* * *}$ & $.736(.055)^{* * *}$ \\
\hline Female*Age 31-35 & $.779(.058)^{* * *}$ & $.781(.058)^{* * *}$ & $.803(.067)^{* * *}$ \\
\hline Female*Age 36-40 & $.987(.075)$ & $.993(.076)$ & $1.001(.091)$ \\
\hline Female*Age 41-45 & $.939(.072)$ & .953 (.073) & .964 (.089) \\
\hline Female*Age 46-50 & $.928(.079)$ & $.939(.081)$ & .908 (.091) \\
\hline Female*Age 51-55 & $.794(.082)$ & $.805(.084)^{* *}$ & $.793(.092)^{* *}$ \\
\hline Female*Age 56-60 & $1.015(.218)^{* * *}$ & $1.018(.219)$ & $.922(.223)$ \\
\hline Weeks of experience & $1.000(.0001)^{* * *}$ & $1.00(.0001)^{* * *}$ & $1.000(.0001)^{* * *}$ \\
\hline Weeks of experience squared & $.999(6,50 \mathrm{e}-08)^{* * *}$ & $.999(6.51 \mathrm{e}-08)^{* * *}$ & $.999(7.44 \mathrm{e}-08)^{* * *}$ \\
\hline Weeks of tenure & $.999(.0002)^{* * *}$ & $.999(.000)^{* * *}$ & $.999(.0003)^{* * *}$ \\
\hline Weeks of tenure squared & $1.00(3,76 e-07)$ & $1.00(3.77 e-07)$ & $1.00(3,96 e-07)$ \\
\hline Unskilled worker & $.970(.027)$ & $.973(.027)$ & $.980(.032)$ \\
\hline Skilled worker & ---- & ---- & ---- \\
\hline Graduate worker & $.679(.074)^{* * *}$ & $.693(.075)^{* * *}$ & $.684(.079)^{* * *}$ \\
\hline Year dummies & yes & yes & yes \\
\hline Industry dummies & yes & yes & yes \\
\hline Occupation dummies & no & yes & no \\
\hline Log-Likelihood & -49744.22 & -49685.351 & -39262.785 \\
\hline Number of individuals & 8655 & 8648 & 7185 \\
\hline Number of Observations & 8797 & 8790 & 7185 \\
\hline
\end{tabular}

Note: Sample of displaced workers age 20 to 60 from IABS 1975-2001. Robust standard errors are reported in parenthesis. * Significance at 10 percent level. ** Significance at 5 percent level. *** Significance at 1 percent level. 
Table 5: Proportional Hazard Estimation of the Length of Displacement Using Two Year Age Categories

\begin{tabular}{|c|c|c|c|}
\hline & $\begin{array}{c}\text { Entire Sample } \\
\text { (1) }\end{array}$ & $\begin{array}{l}\text { Entire Sample } \\
\text { (2) }\end{array}$ & $\begin{array}{c}\text { First Displacement Sample } \\
\text { (3) }\end{array}$ \\
\hline Age 23-24 & $.901(.076)$ & $.911(.077)$ & $.921(.079)$ \\
\hline Age 25-26 & $.866(.075)^{*}$ & $.872(.075)$ & $.839(.075)^{*}$ \\
\hline Age 27-28 & $.721(.061)^{* * *}$ & $.719(.061)^{* * *}$ & $.685(.064)^{* * *}$ \\
\hline Age 29-30 & $.642(.058)^{* * *}$ & $.651(.059)^{* * *}$ & $.646(.063)^{* * *}$ \\
\hline Age 31-32 & $.606(.057)^{* * *}$ & $.610(.058)^{* * *}$ & $.595(.062)^{* * *}$ \\
\hline Age 33-34 & $.647(.065)^{* * *}$ & $.649(.066)^{* * *}$ & $.662(.073)^{* * *}$ \\
\hline Age 35-36 & $.470(.051)^{* * *}$ & $.475(.052)^{* * *}$ & $.474(.057)^{* * *}$ \\
\hline Age 37-38 & $.577(.067)^{* * *}$ & $.581(.067)^{* * *}$ & $.589(.075)^{* * *}$ \\
\hline Age $39-40$ & $.525(.065)^{* * *}$ & $.529(.066)^{* * *}$ & $.505(.070)^{* * *}$ \\
\hline Age 41-42 & $.452(.060)^{* * *}$ & $.452(.061)^{* * *}$ & $.469(.070)^{* * *}$ \\
\hline Age 43-44 & $.438(.059)^{* * *}$ & $.436(.059)^{* * *}$ & $.456(.069)^{* * *}$ \\
\hline Age 45-46 & $.450(.063)^{* * *}$ & $.451(.064)^{* * *}$ & $.466(.075)^{* * *}$ \\
\hline Age 47-48 & $.401(.062)^{* * *}$ & $.398(.061)^{* * *}$ & $.397(.069)^{* * *}$ \\
\hline Age 49-50 & $.367(.059)^{* * *}$ & $.373(.059)^{* * *}$ & $.415(.076)^{* * *}$ \\
\hline Age 51-52 & $.304(.051)^{* * *}$ & $.302(.051)^{* * *}$ & $.372(.072)^{* * *}$ \\
\hline Age 53-54 & $.275(.050)^{* * *}$ & $.273(.050)^{* * *}$ & $.287(.061)^{* * *}$ \\
\hline Age 55-56 & $.119(.025)^{* * *}$ & $.118(.026)^{* * *}$ & $.135(.033)^{* * *}$ \\
\hline Age 57-58 & $.063(.016)^{* * *}$ & $.062(.016)^{* * *}$ & $.066(.019)^{* * *}$ \\
\hline Age 59-60 & $.044(.017)^{* * *}$ & $.045(.017)^{* * *}$ & $.036(.017)^{* * *}$ \\
\hline Female*Age 20-22 & $.891(.072)$ & $.913(.075)$ & .904 (.077) \\
\hline Female *Age 23-24 & $.866 \quad(.085)$ & $.882(.088)$ & $.880(.089)$ \\
\hline Female*Age 25-26 & $.694(.071)^{* * *}$ & $.708(.073)^{* * *}$ & $.789(.085)^{* * *}$ \\
\hline Female*Age 27-28 & $.741(.075)^{* * *}$ & $.761(.077)^{* * *}$ & $.756(.085)^{* * *}$ \\
\hline Female*Age 29-30 & $.725(.075)^{* * * *}$ & $.732(.076)^{* * *}$ & $.749(.088)^{* * *}$ \\
\hline Female*Age 31-32 & $.749(.090)^{* * *}$ & $.755(.091)^{* * *}$ & $.826(.106)$ \\
\hline Female*Age 33-34 & $.717(.079)^{* * *}$ & $.721(.080)^{* * *}$ & $.677(.084)^{* * *}$ \\
\hline Female*Age 35-36 & $.983(.125)$ & $.989(.125)$ & $1.14(.170)$ \\
\hline Female*Age 37-38 & $.888(.102)$ & $.896(.104)$ & $.812(.111)$ \\
\hline Female*Age 39-40 & $1.07(.127)$ & 1.07 (.128) & $1.17(.165)$ \\
\hline Female*Age 41-42 & $1.01(.123)$ & $1.02(.125)$ & $1.00(.143)$ \\
\hline Female*Age 43-44 & $.882(.110)$ & $.891(.111)$ & $.955(.141)$ \\
\hline Female*Age 45-46 & $.926(.103)$ & $.945(.104)$ & $.903(.125)$ \\
\hline Female*Age 47-48 & $.960(.120)$ & $.979(.133)$ & $.951(.154)$ \\
\hline Female*Age 49-50 & $.870(.123)$ & $.871(.123)$ & $.845(.133)$ \\
\hline
\end{tabular}




\begin{tabular}{|c|c|c|c|}
\hline & $\begin{array}{c}\text { Entire Sample } \\
\text { (1) } \\
\end{array}$ & $\begin{array}{l}\text { Entire Sample } \\
(2) \\
\end{array}$ & $\begin{array}{c}\text { First Displacement Sample } \\
\text { (3) }\end{array}$ \\
\hline Female*Age 51-52 & $.830(.123)$ & $.845(.126)$ & $.787(.130)$ \\
\hline Female *Age 53-54 & $.788(.125)$ & $.799(.128)$ & $.817(.147)$ \\
\hline Female*Age 55-56 & $1.02(.221)$ & $1.03(.224)$ & $.922(.225)$ \\
\hline Female*Age 57-60 & $1.09(.332)$ & $1.09(.333)$ & $1.02(.342)$ \\
\hline Weeks of experience & $1.00(1.47 \mathrm{e}-04)^{* * *}$ & $1.00(1.48 \mathrm{e}-04)^{* * *}$ & $1.00(1.59 \mathrm{e}-04)^{* * *}$ \\
\hline Weeks of experience squared & $.999(7.23 \mathrm{e}-08)^{* * *}$ & $.999(7.23 \mathrm{e}-08)^{* * *}$ & $.999(8.21 \mathrm{e}-08)^{* * *}$ \\
\hline Weeks of tenure & $.999(2.51 \mathrm{e}-04)^{* * *}$ & $.999(2.52 \mathrm{e}-04)^{* * *}$ & $.999(2.69 \mathrm{e} .04)^{* * *}$ \\
\hline Weeks of tenure squared & $1.00(3.86 e-07)$ & $1.00(3.87 e-07)$ & $1.00(4.05 e-07)$ \\
\hline Unskilled worker & $.963(.0268)$ & $.964(.027)$ & $.969(.031)$ \\
\hline Skilled worker & ---- & ---- & ---- \\
\hline Graduate workers & $.696(.076)^{* * *}$ & $.710(.078)^{* * *}$ & $689(-079)^{* * *}$ \\
\hline Dummy for part time & $1.04(.063)$ & $1.04(.063)$ & $1.04(.069)$ \\
\hline Year dummies & yes & yes & yes \\
\hline Industry dummies & yes & yes & yes \\
\hline Occupation dummies & no & yes & no \\
\hline Log-Likelihood & -49707.17 & -49648.563 & -39287.325 \\
\hline Number of Observations & 8797 & 8790 & 7192 \\
\hline
\end{tabular}

Note: Sample of displaced workers age 20 to 60 from IABS 1975-2001. Omitted age group are 20 to 22 year old. Robust standard errors are reported in parenthesis. * Significance at 10 percent level. ${ }^{* *}$ Significance at 5 percent level. *** Significance at 1 percent level. 


\begin{tabular}{|c|c|c|c|c|}
\hline & $\begin{array}{l}\text { Cohort 1951-1955 } \\
\text { (1) }\end{array}$ & $\begin{array}{l}\text { Cohort } 1956-1960 \\
\text { (2) }\end{array}$ & $\begin{array}{c}\text { Cohort } 1961-1965 \\
\text { (3) }\end{array}$ & $\begin{array}{c}\text { Cohort } 1966-1970 \\
\text { (4) }\end{array}$ \\
\hline Age 26-30 & $1.03(.303)$ & $.900(.141)$ & $.952(.181)$ & $.834(.107)$ \\
\hline Age 31-35 & $1.04(.351)$ & $.900(.254)$ & $.999(.227)$ & $.727(.206)$ \\
\hline Age $36-40$ & $.950(.392)$ & $1.05(.348)$ & $.874(.279)$ & \\
\hline Age 41-45 & $.800(.366)$ & $.770(.345)$ & & \\
\hline Age 46-50 & $.510(.256)$ & & & \\
\hline Female*Age20-25 & $.926(.216)$ & $.747(.075)^{* *}$ & $.989(.118)$ & $.757(.101)^{* *}$ \\
\hline Female *Age $26-30$ & $.793(.123)$ & $.797(.117)$ & $.658(.089)^{* *}$ & $.673(.096)^{* *}$ \\
\hline Female*Age 31-35 & $.860(.140)$ & $.774(.126)$ & $.769(.118)^{*}$ & $.631(.221)$ \\
\hline Female*Age 36-40 & $.904(.156)$ & $.948(.145)$ & $.854(.260)$ & \\
\hline Female*Age 41-45 & $.855(.135)$ & $.944(.344)$ & & \\
\hline Female*Age 46-50 & $1.748(.634)$ & $.999(.000)$ & & \\
\hline Weeks of experience & .999 (6.58e-04) & .999 (4.13e.04) & $1.00(6.05 \mathrm{e} .04)^{*}$ & $1.01(.001)^{* * *}$ \\
\hline Weeks of experience squared & 1.00 (3.50e-07) & $1.00(3.45 \mathrm{e}-07)^{* *}$ & .999 (7.53e-07) & $.999(1.89 \mathrm{e}-06)^{* * *}$ \\
\hline Weeks of tenure & $.998(6.03 e .04)^{* * *}$ & $.999(7.32 \mathrm{e}-04)$ & $.997(7.93 \mathrm{e}-04)^{* * *}$ & $.995(.001)^{* * *}$ \\
\hline Weeks of tenure squared & $1.00(8.51 \mathrm{e}-07)^{* *}$ & $.999(1.31 \mathrm{e}-06)^{*}$ & $1.00(1.49 \mathrm{e}-06)^{* * *}$ & $1.00(21.04 \mathrm{e}-06)^{* * *}$ \\
\hline Unskilled worker & $.927(.069)$ & $1.08(.068)$ & $.998(.072)$ & $.987(.088)$ \\
\hline Skilled worker & ---- & ---- & ---- & ---- \\
\hline Graduate worker & $.531(.143)^{* *}$ & $.646(.159)^{*}$ & $1.23(.299)$ & $.644(.299)$ \\
\hline Dummy for part time & $.882(.149)$ & $1.14(.169)$ & $1.08(.185)$ & $1.05(.245)$ \\
\hline Log-Likelihood & -5893.84 & -7102.24 & -5838.79 & -3784.53 \\
\hline No of individuals & 1173 & 1368 & 1224 & 872 \\
\hline No of Observations & 1205 & 1393 & 1235 & 876 \\
\hline
\end{tabular}

Note: Sample of displaced workers age 20 to 60 from IABS 1975-2001. Robust standard errors are reported in parenthesis. * Significance at 10 percent level. ** Significance at 5 percent level. *** Significance at 1 percent level. 


\begin{tabular}{|c|c|c|c|}
\hline & $\begin{array}{l}\text { Proportional Hazard } \\
\text { Model with Time } \\
\text { Dependence }\end{array}$ & $\begin{array}{l}\text { Proportional Hazard } \\
\text { Model with Time } \\
\text { Dependence and } \\
\text { unobserved } \\
\text { heteriogeneity }\left({ }^{*}\right)\end{array}$ & $\begin{array}{l}\text { Mixed proportional hazard } \\
\text { model }\left({ }^{*}\right)\end{array}$ \\
\hline Age $26-30$ & $.775(.044)^{\star \star \star}$ & $.728(.057)^{\star \star \star}$ & $.530(.079)^{\star \star \star}$ \\
\hline Age 31-35 & $.656(.045)^{\star \star \star}$ & $.584(.054)^{\star \star \star}$ & $.335(.058)^{\star \star \star}$ \\
\hline Age $36-40$ & $.616(.053)^{\star \star \star}$ & $.551(.064)^{\star \star \star}$ & $.250(.053)^{\star \star \star}$ \\
\hline Age $41-45$ & $.538(.056)^{\star \star *}$ & $.459(.063)^{\star \star \star}$ & $.176(.045)^{\star \star \star}$ \\
\hline Age $46-50$ & $.484(.058)^{\star \star \star}$ & $.406(.064)^{\star \star \star}$ & $.124(.036)^{\star \star \star}$ \\
\hline Age $51-55$ & $.339(.049)^{\star \star \star}$ & $.255(.047)^{\star \star \star}$ & $.051(.017)^{\star \star \star}$ \\
\hline Age $56-60$ & $.090(.018)^{\star \star \star}$ & $.056(.014)^{\star \star \star}$ & $.004(.001)^{\star \star \star}$ \\
\hline Female*Age $20-25$ & $.879(.051)^{\star \star}$ & $.848(.066)^{\star \star}$ & $.858(.130)$ \\
\hline Female *Age 26-30 & $.700(.047)^{\star \star *}$ & $.628(.055)^{\star \star \star}$ & $.482(.078)^{\star \star \star}$ \\
\hline Female*Age 31-35 & $.769(.058)^{\star \star \star}$ & $.725(.071)^{\star \star \star}$ & $.595(.108)^{\star \star \star}$ \\
\hline Female*Age $36-40$ & $.971(.078)$ & $.920(.092)$ & $1.077(.213)$ \\
\hline Female*Age 41-45 & $.937(.077)$ & $.888(.089)$ & $.953(.190)$ \\
\hline Female*Age $46-50$ & $.920(.082)$ & $.864(.096)$ & $.898(.190)$ \\
\hline Female*Age 51-55 & $.787(.083)^{\star *}$ & $.749(.096)^{\star *}$ & $.664(.150)^{\star}$ \\
\hline Female*Age 56-60 & $.984(.206)$ & .994 ( . .229) & $1.037(.378)$ \\
\hline Weeks of experience & $1.00(1.33 e-04)^{\star \star *}$ & $1.000(.000)^{\star \star \star}$ & $1.001(.000)^{\star \star *}$ \\
\hline Weeks of experience squared & $.999(.6 .65 \mathrm{e}-08)^{\star \star \star}$ & $.999(8.28 \mathrm{e}-08)$ & $.999(1.48 \mathrm{e}-07)^{\star \star \star}$ \\
\hline Weeks of tenure & $.999(2.48 \mathrm{e}-04)^{\star \star \star}$ & $.998(.000)^{\star \star \star}$ & $.997(.000)$ \\
\hline Weeks of tenure squared & $1.00(3.80 \mathrm{e}-07)$ & $1.000(4.65 \mathrm{e}-07)^{\star \star \star}$ & $1.000(8.01 \mathrm{e}-07)^{\star \star}$ \\
\hline \multicolumn{4}{|l|}{ Education (omitted group:skilled) } \\
\hline Unskilled & $.967(.028)$ & $.959(.035)$ & $.936 \quad(.065)$ \\
\hline Graduate & $.665(.071)^{\star \star \star}$ & $.606(.082)^{\star \star \star}$ & $.422(.100)^{\star \star \star}$ \\
\hline Full-time job & $1.080(.065)$ & $1.103(.085)$ & $1.1675(.165)$ \\
\hline \multicolumn{4}{|l|}{ Duration } \\
\hline 27-52 weeks & $.44(.015)^{\star \star \star}$ & $.558(.030)^{\star \star \star}$ & \\
\hline 53-78 weeks & $.246(.012)^{\star \star \star}$ & $.302(.022)^{\star \star \star}$ & \\
\hline 79-104 weeks & $.128(.009)^{\star \star \star}$ & $.139(.013)^{\star \star *}$ & \\
\hline $105-130$ weeks & $.08(.007)^{\star \star \star}$ & $.080(.009)^{\star \star \star}$ & \\
\hline 131-156 weeks & $.041(.005)^{\star \star \star}$ & $.036(.005)^{\star \star \star}$ & \\
\hline 157-182 weeks & $.023(.004)^{\star \star \star}$ & $.019(.003)^{\star \star \star}$ & \\
\hline 183-208 weeks & $.017(.003)^{\star \star \star}$ & $.014(.003)^{\star \star \star}$ & \\
\hline 209-234 weeks & $.013(.003)^{\star \star \star}$ & $.010(.002)^{\star \star \star}$ & \\
\hline 235-260 weeks & $.014(.003)^{\star \star \star}$ & $.011(.003)^{\star \star \star}$ & \\
\hline 260 and more weeks & $.001(.000)^{\star \star \star}$ & $.001(.000)^{\star \star \star}$ & \\
\hline Duration dependence & yes & yes & yes \\
\hline Log-Likelihood & -14743.14 & -14660.522 & -17205.044 \\
\hline Number of individuals & 8654 & 8654 & 8654 \\
\hline
\end{tabular}

Note: Sample of displaced workers age 20 to 60 from IABS 1975-2001. All regression contain dummy variable for year and industry.Robust standard errors are reported in parenthesis. $(*)$ We assume the inverse gaussian distribution for the unobserved heterogeneity component. * Significance at 10 percent level. ** Significance at 5 percent level.

*** Significance at 1 percent level. 
Table 8: Regression Results of the Log Real Daily Wage in the Post-Displacement Job

\begin{tabular}{|c|c|c|c|c|}
\hline Variable & (1) & (2) & (3) & (4) \\
\hline female & $-.277(.012)^{* * *}$ & $-.274(.012)^{* * *}$ & & \\
\hline Age 26-30 & & $.073(.020)^{* * *}$ & $.042(.023)^{*}$ & $.045(.023)^{* *}$ \\
\hline Age 31-34 & & $.038 \quad(.026)$ & $.033(.029)$ & .044 (.029) \\
\hline Age $35-40$ & & $.040 \quad(.035)$ & $.019(.037)$ & $.040 \quad(.037)$ \\
\hline Age 41-45 & & $-.002(.044)$ & $-.014(.046)$ & $.018 \quad(.046)$ \\
\hline Age 46-50 & & $-.047(.056)$ & $-.016 \quad(.058)$ & $.034(.057)$ \\
\hline Age 51-55 & & $-.046 \quad(.071)$ & $-.035 \quad(.072)$ & $.031(.072)$ \\
\hline Age $56-60$ & & $-.060(.095)$ & $-.062(.099)$ & .012 (.099) \\
\hline Female*Age $20-25$ & & & $-.301(.022)^{* * *}$ & $-.301(.022)^{* * *}$ \\
\hline Female *Age 26-30 & & & $-.182(.029) * * *$ & $-.175(.029)^{* * *}$ \\
\hline Female*Age 31-35 & & & $-.275(.033)^{* * *}$ & $-.268(.033)^{* * *}$ \\
\hline Female*Age 36-40 & & & $-.206(.037)^{* * *}$ & $-.196(.037)^{* * *}$ \\
\hline Female*Age 41-45 & & & $-.248(.040)^{* * *}$ & $-.239(.040)^{* * *}$ \\
\hline Female*Age 46-50 & & & $-.426(.043)^{* * *}$ & $-.426(.043)^{* * *}$ \\
\hline Female*Age 51-55 & & & $-.374(.052)^{* * *}$ & $-.374(.052)^{* * *}$ \\
\hline Female*Age 56-60 & & & $-.321(.094)^{* * *}$ & $-.318(.094)^{* * *}$ \\
\hline months of displacement & & & & $-.005(.001)^{* * *}$ \\
\hline experience (experience squared) & yes & yes & yes & yes \\
\hline education & yes & yes & yes & yes \\
\hline year & yes & yes & yes & yes \\
\hline Adjusted R-squared & 0.1945 & 0.1974 & 0.2022 & 0.2214 \\
\hline No. Observations & 4075 & 4075 & 4075 & 4075 \\
\hline
\end{tabular}

Note: Sample of displaced workers age 20 to 60 from IABS 1975-2001 who obtain a full time job after displacement. Robust standard errors are reported in parenthesis. * Significance at 10 percent level. ** Significance at 5 percent level. *** Significance at 1 percent level. 
Table 9: Regressions of the Differences in Log Daily Wages After and Before Displacement

\begin{tabular}{|c|c|c|c|c|}
\hline varianble & (1) & (2) & (3) & (4) \\
\hline female & $-.027(.013)^{* *}$ & $-.024(.013)^{*}$ & & \\
\hline Age 26-30 & & $.014(.021)$ & $.007(.024)$ & $.010(.024)$ \\
\hline Age 31-35 & & $.032 \quad(.027)$ & $.021 \quad(.030)$ & $.030(.030)$ \\
\hline Age 36-40 & & $.085(.036)^{* * *}$ & $.064(.039)^{* * *}$ & $.081(.039)^{* * *}$ \\
\hline Age 41-45 & & $.145(.047)^{* * *}$ & $.121(.048)^{* * *}$ & $.147(.049)^{* * *}$ \\
\hline Age 46-50 & & $.184(.059)^{* * *}$ & $.190(.061)^{* * *}$ & $.229(.061)^{* * *}$ \\
\hline Age 51-55 & & $.248(.075)^{* * *}$ & $.237(.076)^{* * *}$ & $.290(.076)^{* * *}$ \\
\hline Age 56-60 & & $.250(.100)^{* * *}$ & $.224(.104)^{* *}$ & $.282(.104)^{* * *}$ \\
\hline Female*Age 20-25 & & & $-.049(.023)^{* *}$ & $-.049(.024)^{* *}$ \\
\hline Female *Age 26-30 & & & $-.032(.030)$ & $-.027(.030)$ \\
\hline Female*Age 31-35 & & & $-.021 \quad(.035)$ & $-.016 \quad(.035)$ \\
\hline Female*Age 36-40 & & & .021 (.039) & $.030 \quad(.040)$ \\
\hline Female*Age 41-45 & & & $.034 \quad(.042)$ & $.042(.042)$ \\
\hline Female*Age 46-50 & & & $-.079(.045)^{*}$ & $-.079(.045)^{*}$ \\
\hline Female*Age 51-55 & & & $-.004 \quad(.055)$ & $-.004 \quad(.055)$ \\
\hline Female*Age 56-60 & & & $.044 \quad(.099)$ & .047 (.099) \\
\hline months of displacement & & & & $-.004(.001)^{* * *}$ \\
\hline experience (experience squared) & yes & yes & yes & yes \\
\hline education & yes & yes & yes & yes \\
\hline year & yes & yes & yes & yes \\
\hline Adjusted R-squared & 0.0184 & 0.0199 & 0.0198 & 0.033 \\
\hline No. Observations & 4075 & 4075 & 4075 & 4075 \\
\hline
\end{tabular}

Note: Sample of displaced workers age 20 to 60 from IABS 1975-2001 who obtain a full time job after displacement. Robust standard errors are reported in parenthesis. * Significance at 10 percent level. ** Significance at 5 percent level. *** Significance at 1 percent level. 


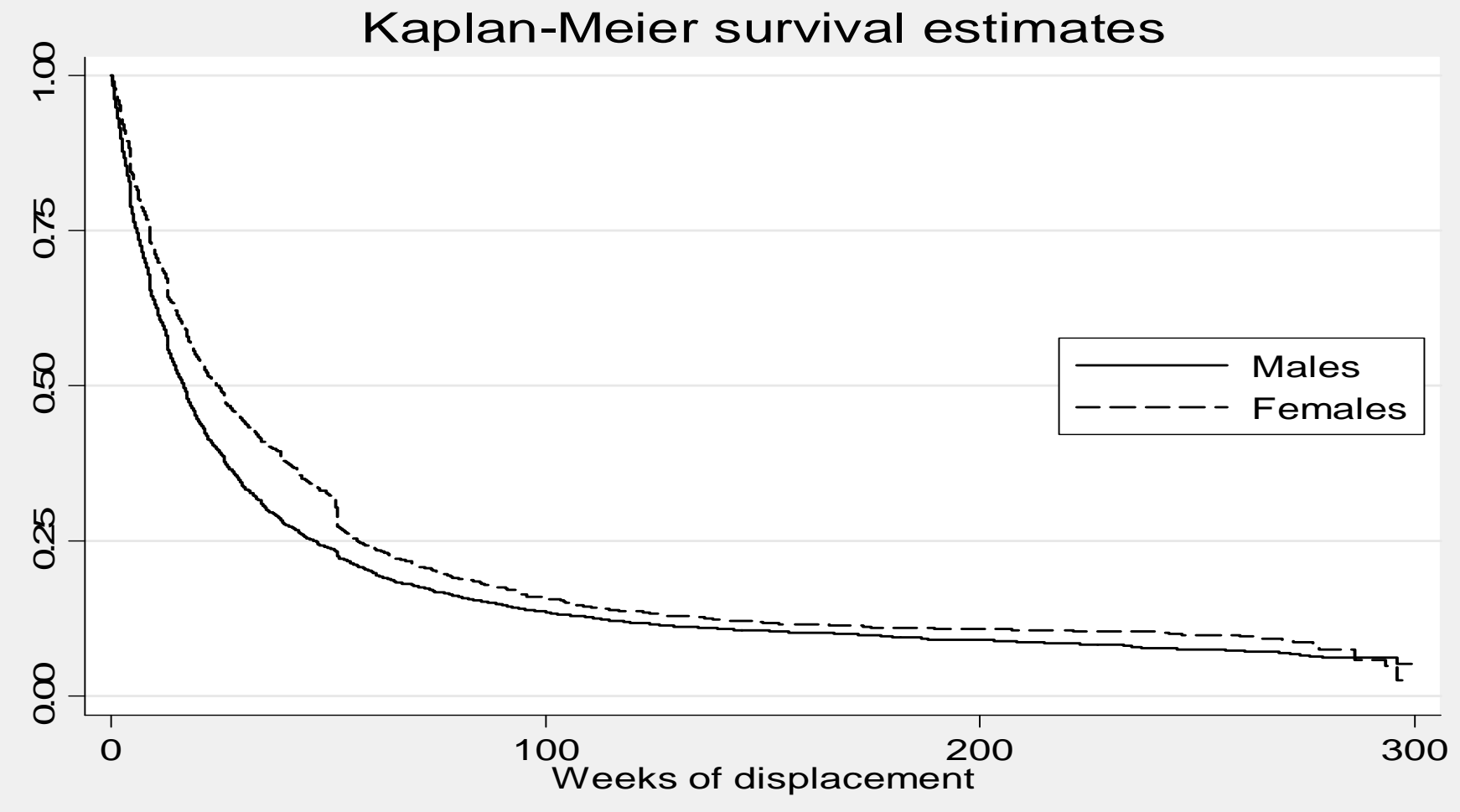

Figure 1: Durations of unemployment 


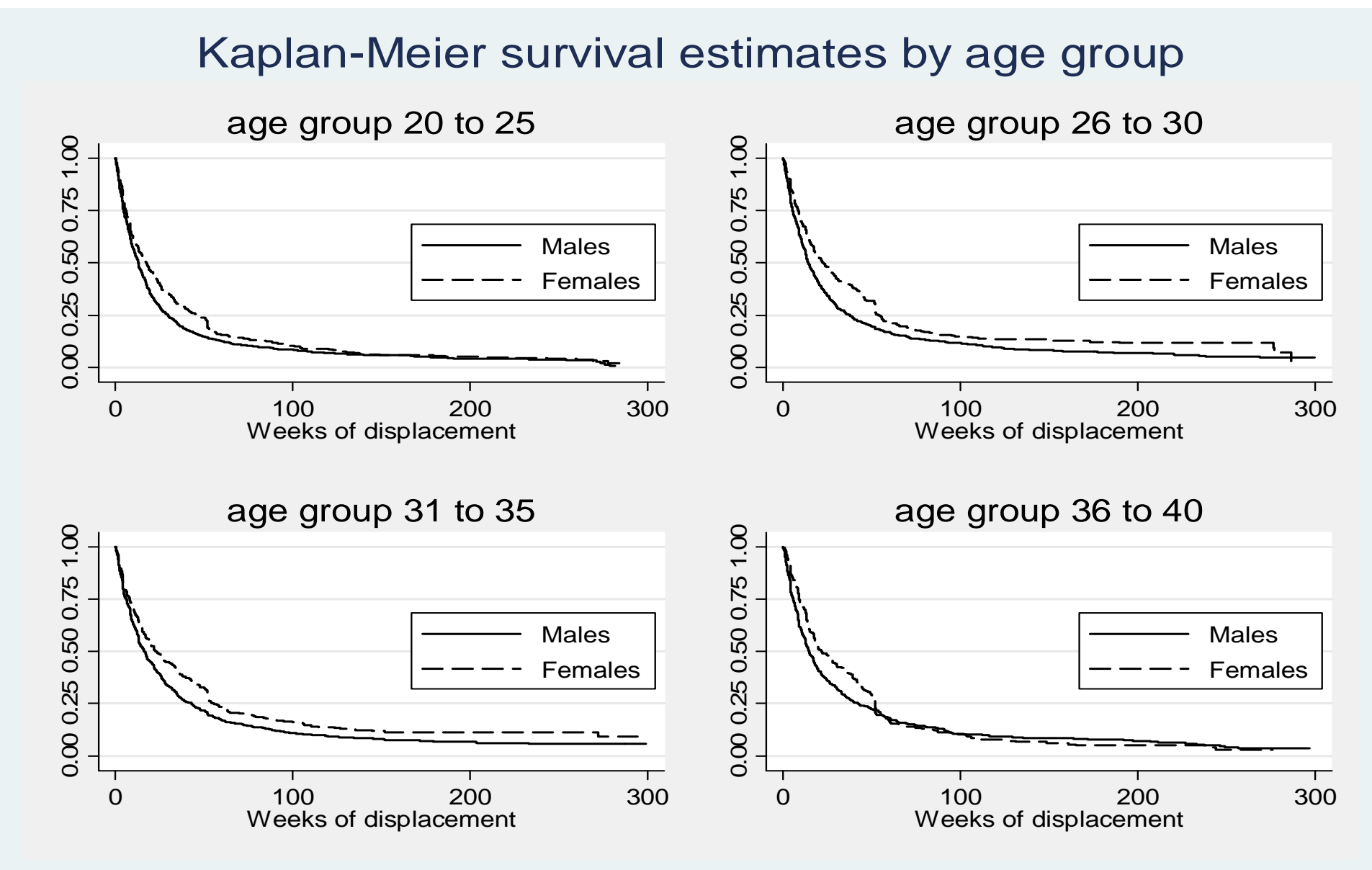

Figure 2a: Durations of unemployment of displaced workers by Gender and Age Group 


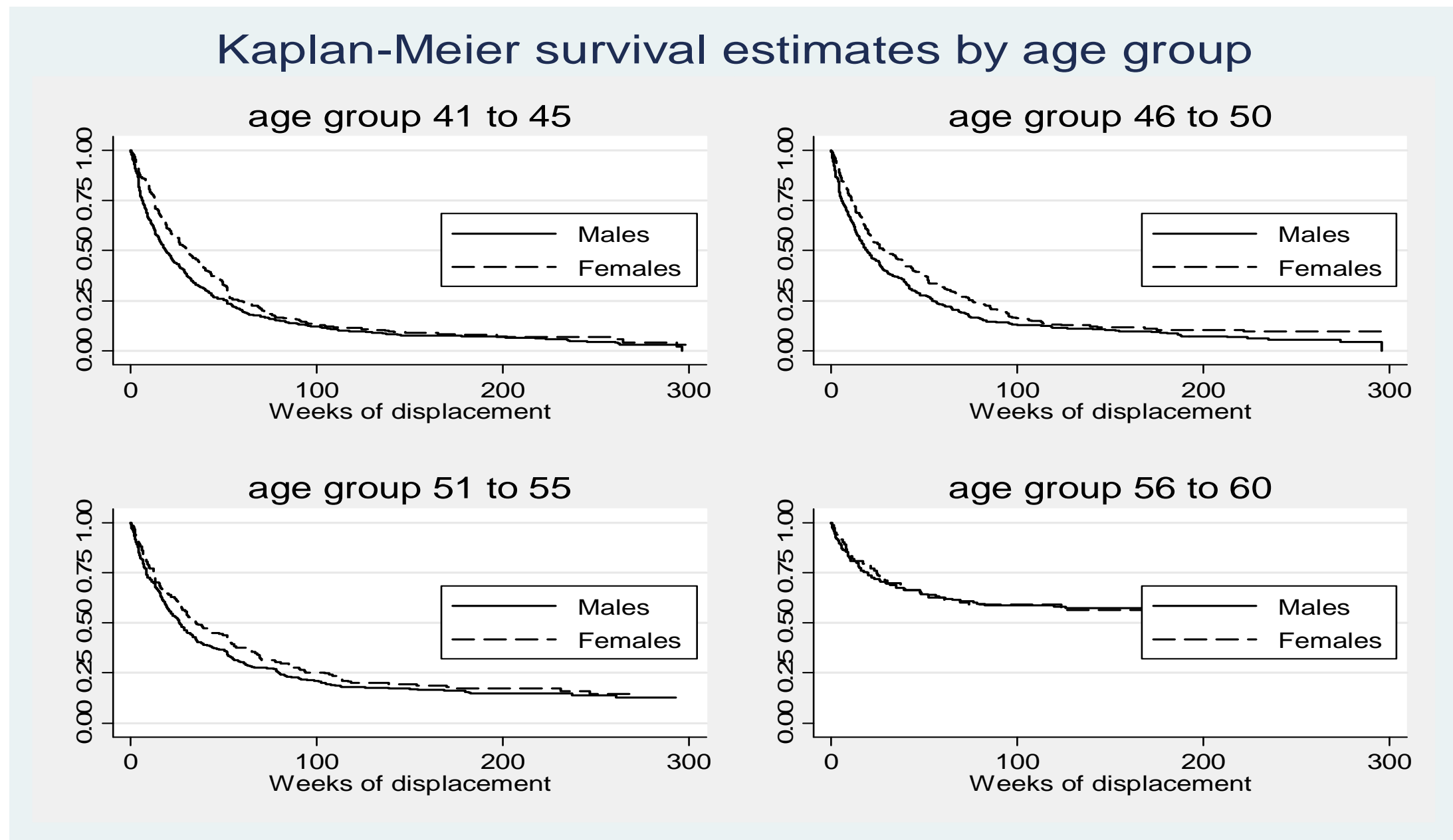

Figure 2b: Durations of unemployment of displaced workers by Gender and Age Group - cont. 